堆積学研究, 52号, 75-83, 2000

J.Sed.Soc.Japan, No. 52, 75-83, 2000

\title{
私が接した堆積学草創期の群像（IV一最終）
}

岡田 博有*

\section{Leaders in sedimentology in its early years (IV-Final)}

\section{Hakuyu Okada*}

\section{Jean Aubouin}

Aubouin（オーボワン）教授（図 48）はフランス 地質学界の重鎮である. 教授は地質学発展史の第 1 期地向斜時代の最後を飾る業績を残しただけでな く，その後の第 2 期プレートテクトニクス新時代に あ乗り換えることができた．教授の名を天下に知ら しめた著書 “Geosynclines” (Aubouin, 1965) は, 海洋底拡大説が提唱され，地質学が新しい時代のう ねりに洗われ始めていた頃に出版された。そのため 現在の地向斜はどこにあるか明確に示さなかった Marshall Kay（1951; 岡田, 2000a）とは違って, Aubouin はその著書な中で「現在の地向斜」の一章 (Chapter 14 : The Geosynclinal Concept and the Present Epoch) を設け（Aubouin, 1965, pp. 229240)，スンダ諸島とその海域こそがそこであると， 過去と現在の明快な対比を行った. 教授に時代の幸 運を感じるのである。

Aubouin 教授は 1928 年 5 月 5 日に Evreux で生 まれ, Saint-Cloud 高等師範学校で学び, ソルボン ヌ大学で D. Sc. 学位, 1961 年より Pierre et Marie Curie 大学教授, 1976 年にはフランス地質学会会長 となり，さらにユネスコ世界地質図委員会委員長 (1980-), フランス科学アカデミー会長 (1989-90), フランス海洋開発委員会委員長 (1985-90), その他 数々の政府機関の要職を歴任した。レショョン・ド ヌール勲章, 国立学術研究所賞, フランス地質学 会・ベルギー地質学会などの学会賞を受賞したほ か, アメリカ地質学会 (1980)・ロンドン地質学会 （1976）各名誉会員，ローマ科学アカデミー

受付 : 2000 年 6 月 16 日

* 応用地質株式会社九州支社

Oyo Corporation Kyushu Branch, 2-21-36 Ijiri, Minami-ku, Fukuoka 811-1302, Japan :
(1974)・ソ連科学アカデミー（1976）・アテネ科学 アカデミー（1980）・ユーゴースラビア科学アカデ ミー（1990）などの会員として顕彰されている.

教授は人を逸らさ㜔密感を示し, 存在感があ る.

\section{Peter Frederick Ballance}

Ballance 博士はニュージーランドを代表する堆 積地質学者である（図 49）。ニュージーランドの造 構環境をよく反映している収束帯ならびに走向移動 断層プレート縁辺部における堆積盆地形成と堆積作 用の関係に関して優れた研究を行った（Ballance, 1974, 1976, 1980). また, 重力流堆積物, 火山性堆積 物に関する研究に成果を挙げた。 とくに, 走向移動 断層带の堆積作用に関する総括は重要な貢献であっ た (Ballance and Reading, 1980).

Ballance 博士はイングランド中部 Staffordshire の Josiah Wedgwood 陶器工場で有名な Stoke-onTrent の出身で, ロンドン大学 Queen Mary College (現 Queen Mary Westfield College) で BSc (1957), Ph. D (1960), さらに収束帯・横ずれプ レート縁辺域の堆積地質学に関する総合的業績に対 して D. Sc.（1996）を取得した. 1960 年からニュー ジーランドの Auckland 大学講師, 1992 年に同準 教授, 1998 年に定年退職し, 現在, 同大学名誉研究 員. ニュージーランド地質学会会長 (1972) を務め たほか，国際的には IAS の評議員（1982-85，199498), Sedimentology 編集委員 (1992-98), Journal of Sedimentary Petrology 編集委員（1989-1992） などを歴任した。

Ballance 博士は身のこなしが軽やかでいかにも 野外地質学者といった印象である. 


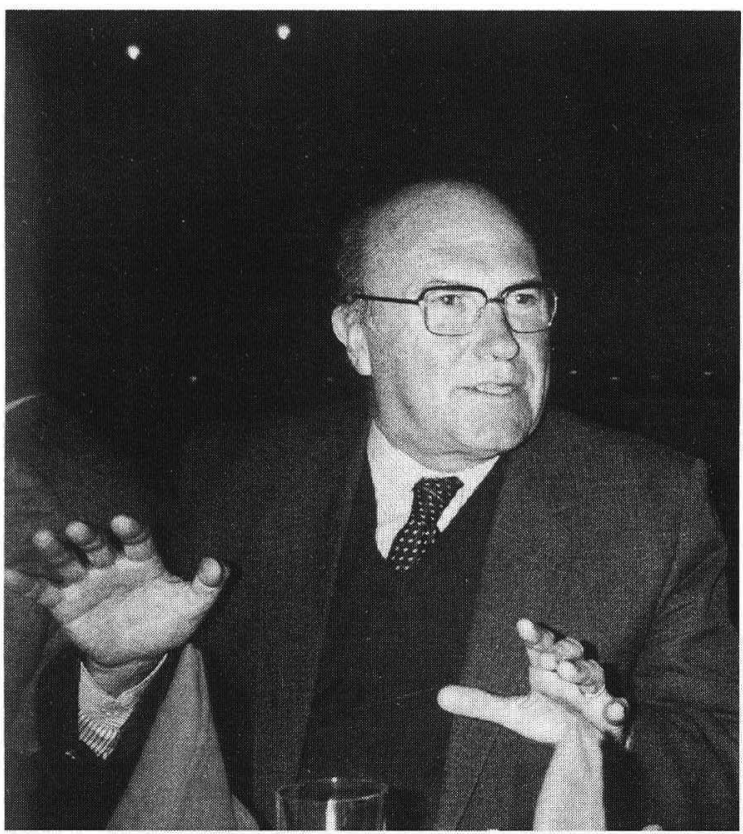

図 48 J. Aubouin 教授（1984 年 12 月 10 日東京 זా).

\section{Sam Boggs, Jr.}

Boggs 教授（図 50）は名著の誉れ高い2 部作 "Principles of sedimentology and stratigraphy" (1987, 1995), "Petrology of sedimentary rocks" （1992）で名声を確立した，とくに前者は，堆積学確 立後初めて堆積学を層序学と結び付けようとする地 質学の基本に立った見識を示した. この後, 同じよ うな考えに立脚した Fritz and Morre (1988; フ リッッ・ムーア［原田訳］，1999）の教科書が現れ た.

Boggs 教授は 1926 年 7 月 28 日北米ケンタッ キー州 King’s Creekに生まれ, Kentucky 大学で BS (1956), Colorado 大学で Ph. D (1964) を取得 した. 職歴として, Phillips Petroleum Co.の石油 探鉱技師 (1956-61), Exxon Production Research Co. 研究員 (1964-65) を経て, 1965 年から Oregon 大学教授として堆積岩石学, 層序学, 石油地質学, 海洋地質学を講じてきた. 1994 年に同大学を定年退 職して, 現在, 名誉教授. この間, 米中科学協力事 業の一環として台湾大学客員教授 (1972-73), 日本 学術振興会招聘による東大海洋研究所客員教授 (1981-82)，1989 年には ODP Leg 127 (日本海)の乗 船研究員を務めた.

Boggs 教授の研究は電子顕微鏡, EPMA, catho-

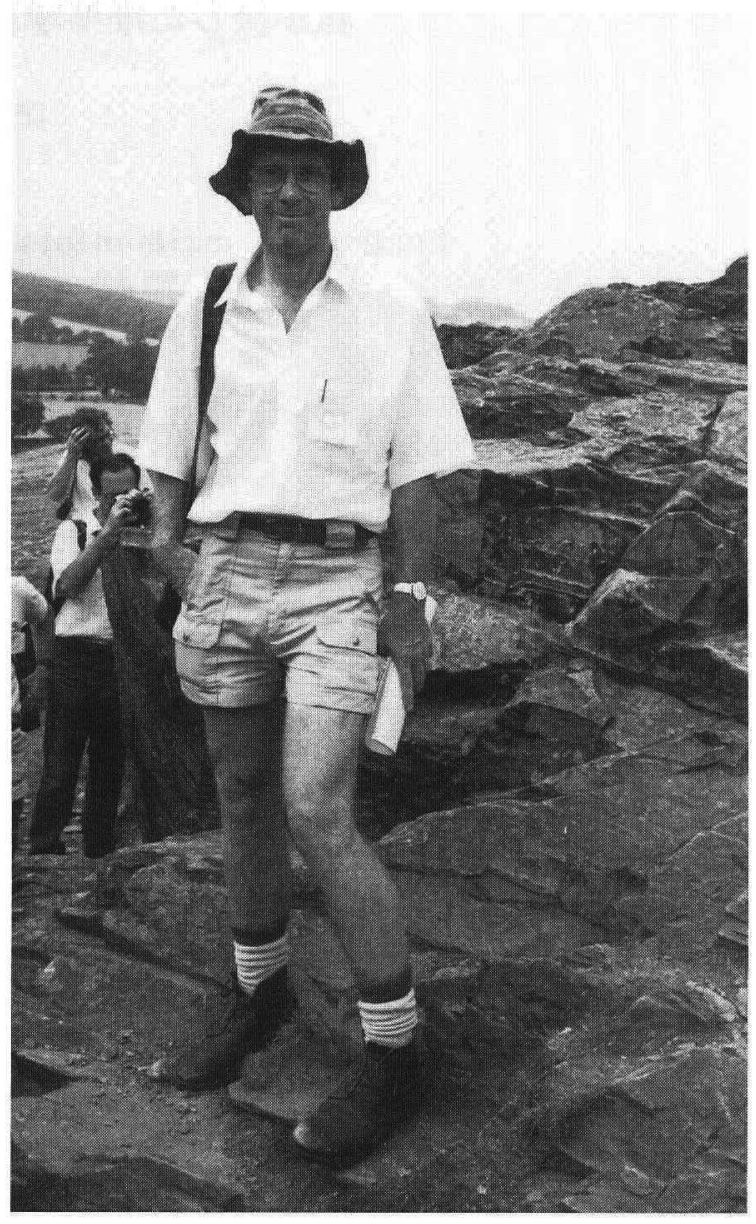

図 49 P.F. Ballance 博士（1990 年 8 月 29 日イギリ ス Nottingham 近郊の原生代化石産地で有名な Charnwood 丘陵で).

doluminescence を使った堆積岩岩石学が中心で, 砕屋物の供給源・運搬・続成過程の解明に大きい業 績を挙げた。 とくに興味深い研究として, 砂岩の記 号式分類法（Boggs, 1967）, 日本列島周辺海域の海 底堆積物コアの分析記載 (Boggs, 1984), 堆積物の 電子顕微鏡観察 (Boggs et al., 1998) などがある. Boggs（1984）は東大海洋研究所在籍時代の成果で ある。また，本誌にむ 2 編の投稿論文がある (Boggs et al., 1993, 1996).

Boggs 教授の知られざる一面として, 研究生活に 入る前の 1949 年から, 当時横浜にあった米軍医療 兵站基地で 1953 年まで軍属として働いていたこと がある。このとき Setsuko夫人と結ばれた。当時は 朝鮮戦争の最中であった. 1953 年末に帰国, BS を 


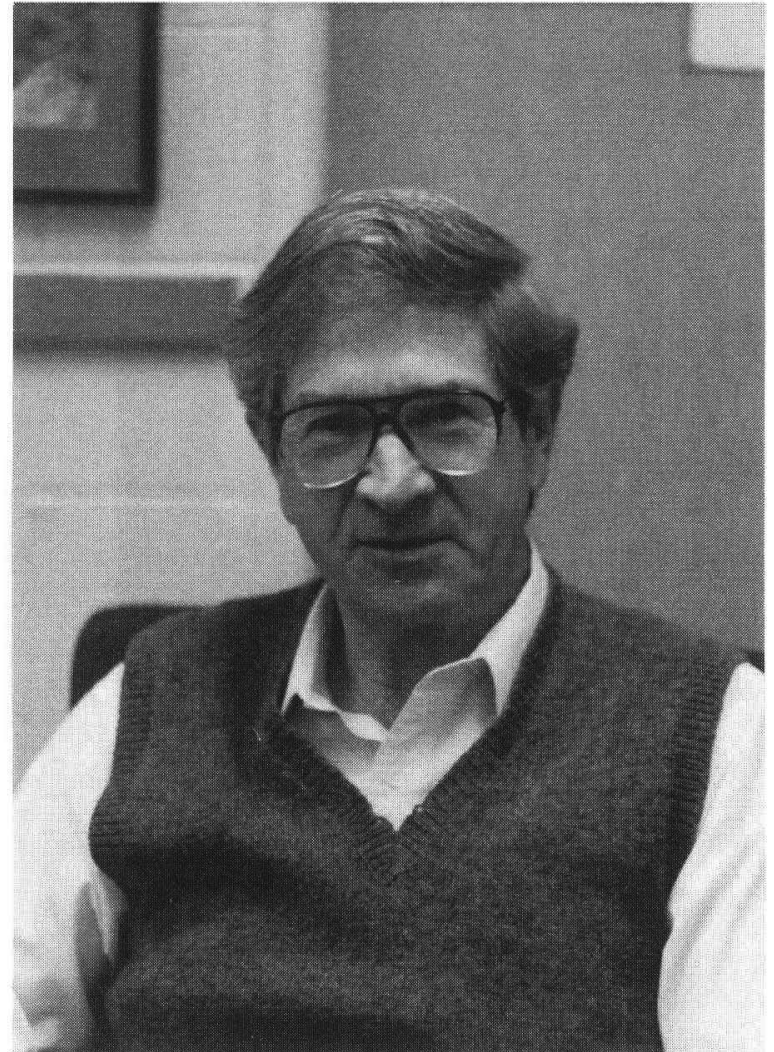

図 50. S. Boggs 教授（2000 年 3 月 13 日, Boggs 教授提供).

取るため Kentucky大学に入ったという. Boggs 教授の日本との密接な関係はすでにこの時から始 まっていた。

\section{Sampat Kumar Tandon}

Tandon 教授はインドを代表する堆積学者（図 51, 52). 彼は 1981 年之 1988 年の 2 回日本学術振興 会の招聘研究員として来日したほか, 国際集会なよ゙ で度々訪日しているので，日本に知己が多い。 Tandon 教授は1945年8月13日にDelhi で生ま れ，パンジャブ大学でB. Sc. (1965), M. Sc. （1966），デリー大学で Ph. D (1972）を取得した. そ の後, ニューデリーの Indian Institute of Technology の講師 (1966-68), Dehra Dun にある Wadia Institute of Himalayan Geology 研究員 (1971-76) を経て，1976 年からデリー大学地質学科 Reader, 1986 年には同大学教授として現在に至る。また， 1992-93 年にはデリー大学理学部長を務めた.

彼の研究上の関心は幅広いが，とくに古土壤や力

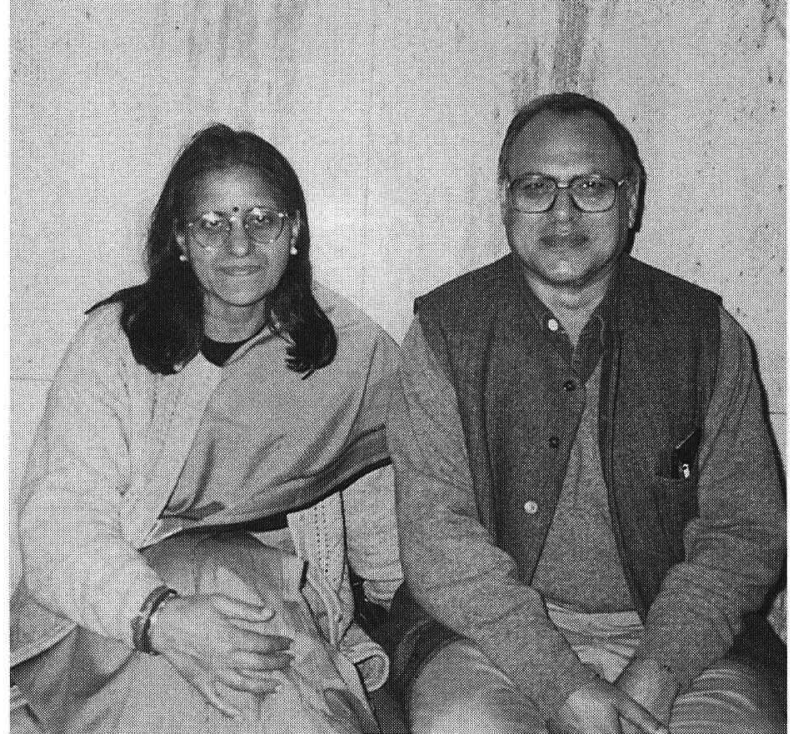

図 51 S. K. Tandon 教授と夫人（1997 年 12 月 8 日 New Delhi のインド科学アカデミー [INSA] で).

ルクリートの生成過程などの乾燥地域堆積学に造詣 が深い（Tandon and Gibling, 1997). ヒマラヤ地域 の活構造之堆積作用の関係 (Tandon, 1976) やデカ ン地域の白巠紀古環境解析 (Tandon et al., 1995) などについても優れた研究がある. 滞日中の研究成 果には Okada and Tandon（1984）がある.

Tandon 教授の優れた業績を顕彰して, Young Scientists Medal (INSA, 1974), Krishnan Gold Medal (Indian Geophysical Union, 1985), Bhatnagar Prize in Earth Sciences (Council of Scientific and Industrial Research, 1988) に輝い ているほか, Indian National Science Academy, New Delhi (1999), Indian Academy of Sciences, Bangalore (1999), Third World Academy of Sciences（TWAS : 本部事務局はイタリア Triesteに ある)（2000）の各 Fellow に推挙されている. 198995 年にはインド堆積学会副会長を務めた.

Tandon 教授は温厚, 誠実, 静かな思索家であり, 周りから絶大な信頼を寄せられ敬愛されている.

\section{Rudolf Trümpy}

Trümpy 教授はスイス連邦工科大学教授として 全精力をスイス・アルプスの地質学的研究に傾注さ れた（図 53）。教授は 1921 年 8 月 16 日 Glarus に生 まれ，ローザンヌ大学卒業，1947 年には同助教授， 


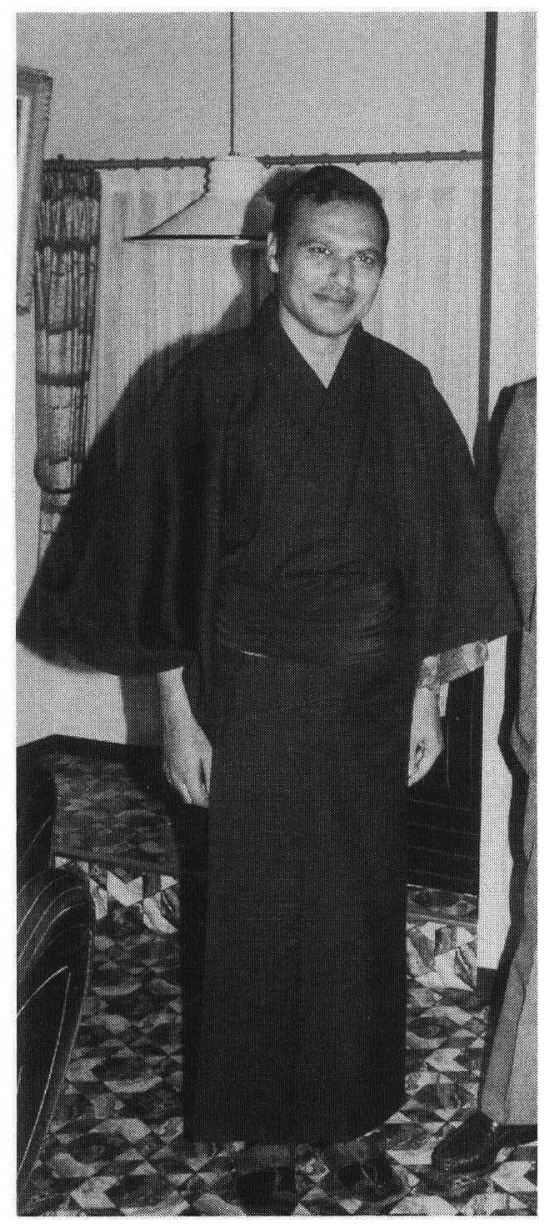

図 52 和服姿がよく似合う Tandon 教授（1981 年 9 月 25 日静岡市で).

1953 年からスイス連邦工科大学教授.

地質学第 1 期（地向斜時代）から第 2 期（プレー トテクトニクス時代）の過渡期に, アルプス研究か ら世界の造山帯地層研究に甚大な影響を与えた。 と くに, スイス・アルプスで行った造山時階と堆積相 の関係解析は画期的貢献であった（Trümpy， 1960).

Richard A.F. Penrose, Jr. Medal (GSA, 1985) を受賞し，現在アメリカ地質学会名誉会員.

Trümpy 教授には気さくな人柄を感じた.

\section{Peter R. Vail}

Vail 教授はテキサス州ヒューストンの Rice 大学 地質学科の W. Maurice Ewing Professor of Oceanography (図 54). 音響層序学 (seismic stratigraphy）（Vail et al., 1977）・シーケンス層序学（se-

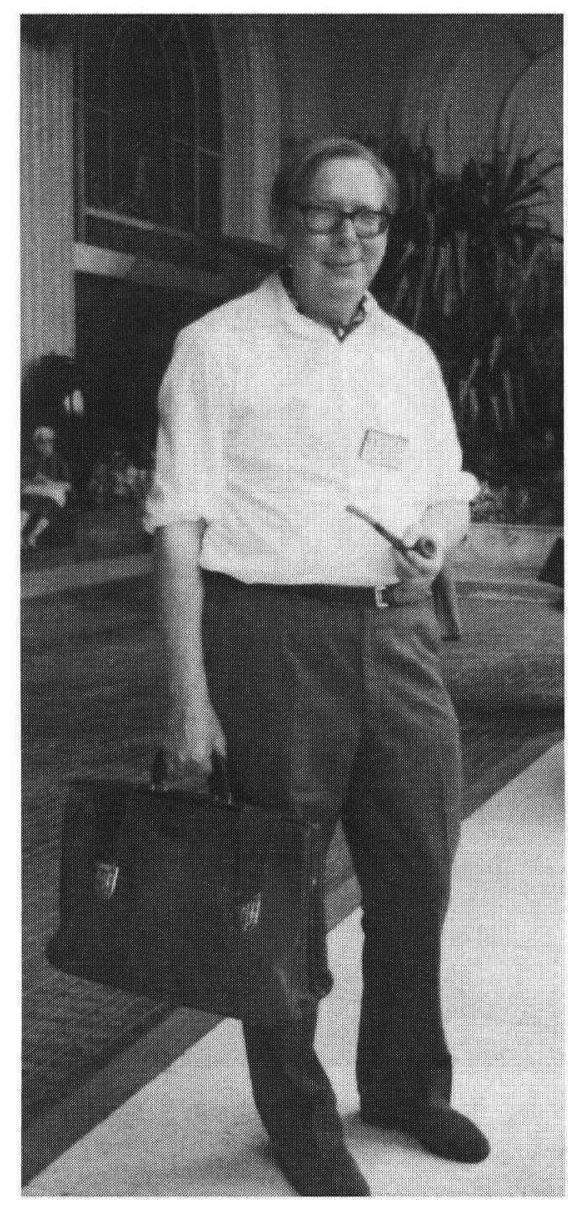

図 53 R. Trümpy 教授（1975 年 7 月 11 日フランス Nice で).

quence stratigraphy）（Vail, 1987）の提唱者とし て, 現在, 地層研究の最先端にあって世界の堆積学 層序学をリードしている（岡田，1998）.

Vail 教授は 1930 年 1 月 30 日ニューヨーク市で 生まれ, Dartmouth College で MS (1952), Northwestern Univ. で MS と Ph. D (1956) を取得した. その後, 直ちに Exxon Production Research Co. 研究員 (1956-86) となり，1986 年から現職.

Vail 教授は包容力のある落ち着いた人柄で, 多く の研究者を統率して新しい分野を開拓した指導者と しての片鱗が伺える. Virgil Kauffman Gold Medal (1976), William Smith Medal（1986）なよ゙ を受賞している.

\section{Franklyn Bosworth van Houten}

Princeton 大学名誉教授 van Houten（図 55）は 


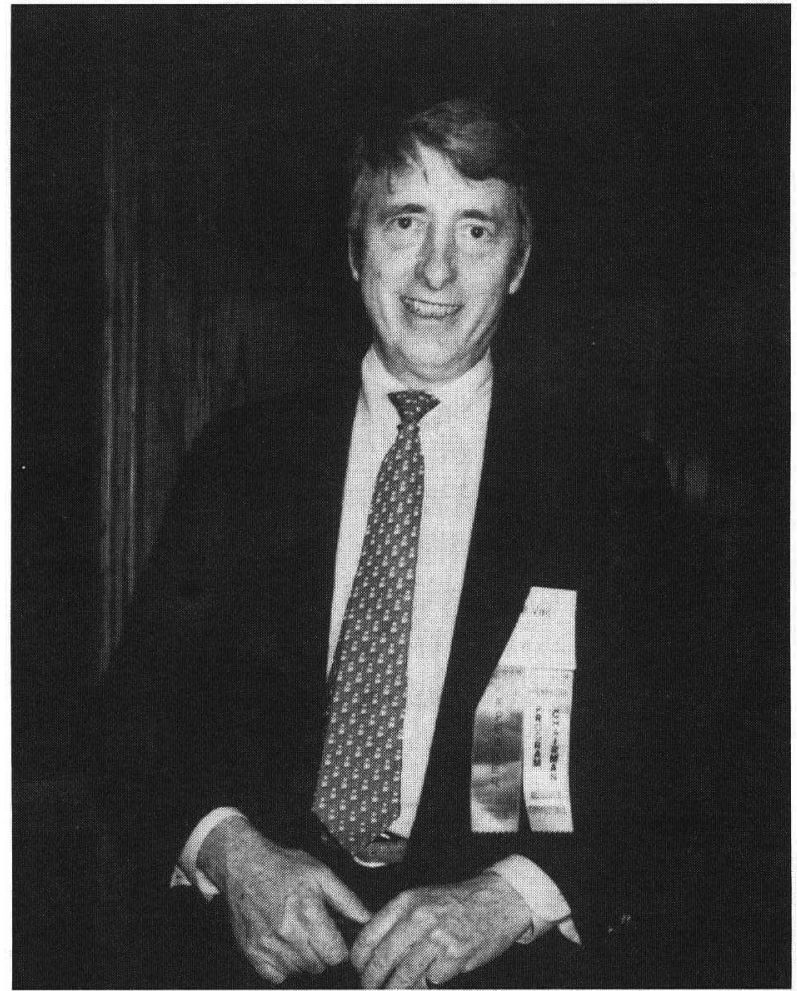

図 54 P.R. Vail 教授（1990 年 12 月 3 日 Houston で).

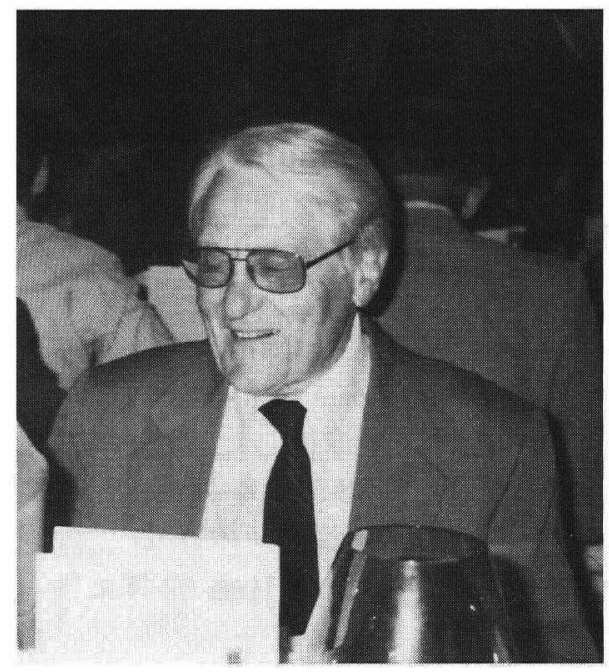

図 55 F.B. van Houten 教授（1990 年 8 月 30 日 Nottingham で).

赤色堆積物, 酸化鉄含有堆積物の研究で咸に名声を 博していた. まさに堆積学最初期を飾る大先達であ る.
1914 年 7 月 14 日にニューヨーク市で生まれ， Rutgers大学でBS (1936), Princeton大学で Ph. D (1941) を取得した. 1947 年から 1985 年まで Princeton 大学の助教授，教授を歴任. 1985 年に同 大学名誉教授. SEPM の Twenhofel Medal を受賞 した.

van Houten 教授の代表作を数編挙げると, van Houten (1961，1968，1972，1973）などがあり，い ずれあ赤色層研究のベンチマーク的作品である.

van Houten 教授は温厚な好々爺之いった印象 で，現在も Princeton で健在である.

\section{Roger Geoffrey Walker}

1960 年代後半から 1980 年代にかけて先頭に立っ て堆積学を引っ張ってきた R. G. Walker 教授は カナダ McMaster 大学の名誉教授 (図 56). G. V. Middleton 教授 (岡田, 2000a) と並んでカナダ堆積 学の双頭の鷲といえよう.

Walker 教授は 1939 年 3 月 26 日にロンドンで生 まれ，Oxford 大学で BA (1961)，D. Phil.（1964）

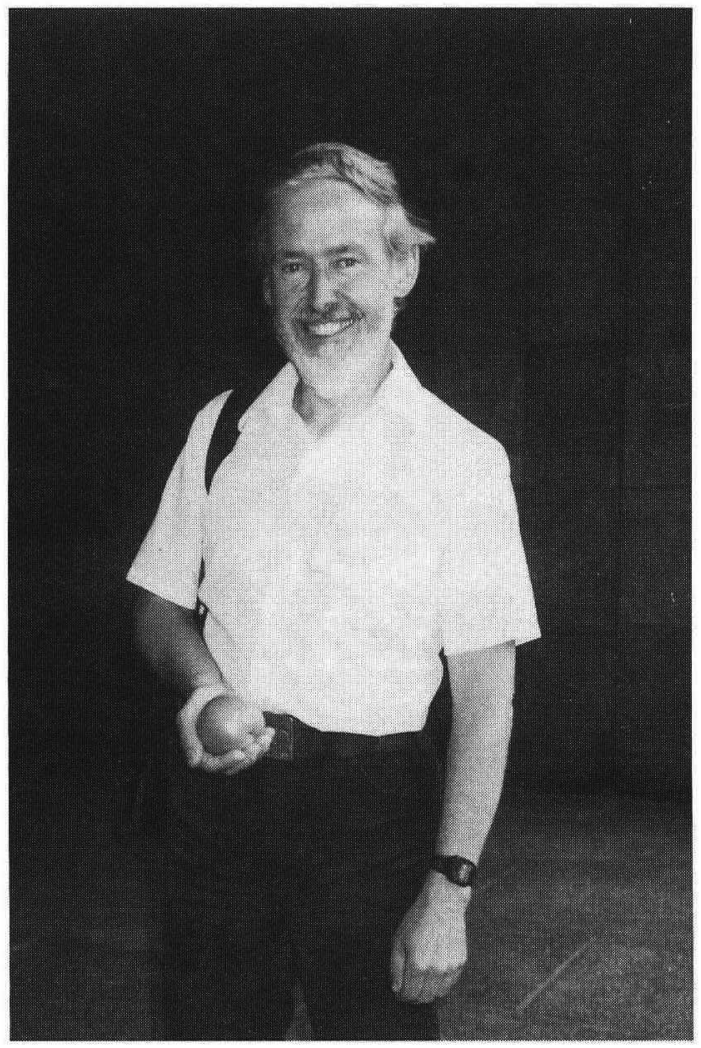

図 56 R.G. Walker 教授（1990 年8月 27 日 Nottingham 大学で). 
を受けた. Oxford での指導教官は H. G. Reading 博士（岡田, 2000b) であった.

学位取得後, Walker 教授は NATO post-doc fellow として Johns Hopkins大学のF. J. Pettijohn 教授の許にあったが (1964-66)，1966 年 から McMaster 大学助教授, 1973 年に同教授に昇 進した。1998 年には定年退職して同大学名誉教授.

タービダイトと海底扇状地堆積物の野外地質学的 研究が Walker 教授の研究の中心であった. アイデ アと先見性のある論文を発表し続け, A. H. Bouma (岡田，1999）によって先鞭をつけられたタービダイ 卜の研究を飛躍的に発展させた功績は高く評価され る。主な業績として Walker (1965，1975，1978， 1985), Walker and James（1992）を挙げることが できよう。

Walker 教授は小柄で，常に笑みを浮か心゙，人 懐っこい.

\section{Ewart Kendall Walton}

St. Andrews 大学名誉教授 E. K. Walton 博士 （図 57）はイギリスにおける近代堆積学の先駆者で ある.

Walton 教授は 1924 年 11 月 24 日 Northumberland の炭鉱町 Ashington で生まれ，第二次世界大

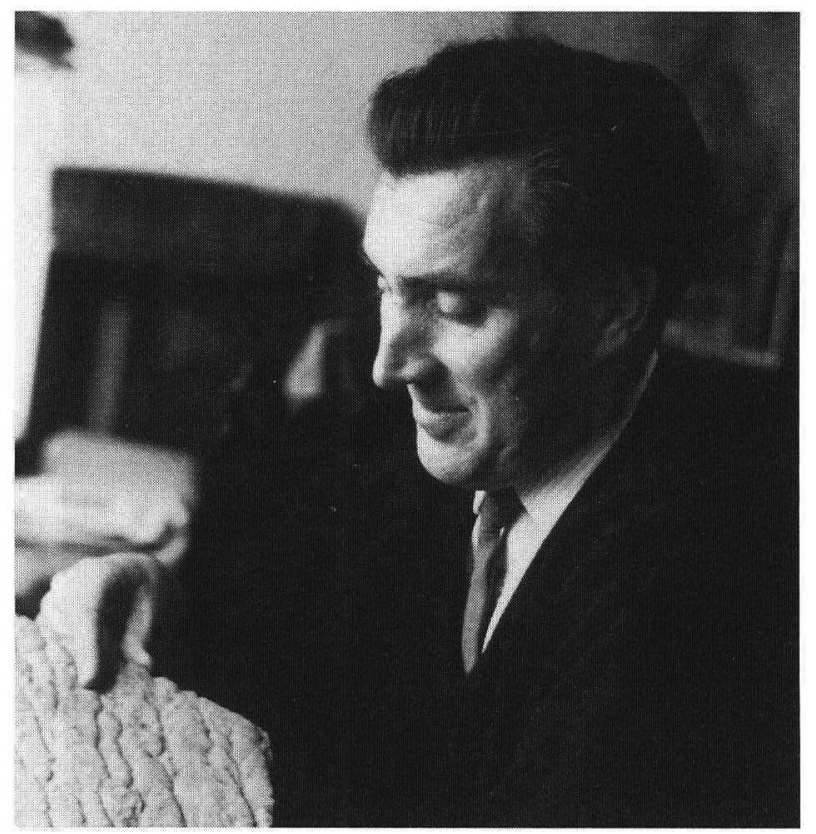

図 57 E.K. Walton 教授（1965 年 7 月 31 日エジン バラ大学研究室で).
戦でイギリス空軍に徴用された（1944-49）。その後 Durham 大学で B. Sc (1949), Ph. D (1952) を取 得. グラスゴー大学地質学科助手 (1951-54), エジン バラ大学講師 (1954-64), 同大学 Reader (1964-68) を経て，1968 年に St. Andrews 大学教授に就任し た. 1988 年に定年退職して現在同大学名誉教授.

Walton 教授は堆積構造の成因からみた各種環境 の堆積盆地における堆積作用（Walton, 1956, 1967), 堆積サイクルの認定と解析 （Duff and Walton, 1962 ; Duff et al., 1967), 珪質堆積岩の供 給源解明のための堆積岩石学 (Walton, 1955), 炭 化水素胚胎層の続成過程など多彩な研究を行った。

とくに，著書 Dzulynski and Walton（1965）は初 めて堆積構造の分類体系を示し, 大判の露頭写真と 堆積構造の水槽実験生成物を刘応させた，新時代を 告げるような堆積構造学の優れた入門書であった.

教授の業績はエジンバラ学士院会員 (1968), ポー ランド科学アカデミー会員 (1997) として顕彰され ている.

Walton 教授は大柄であるが，気は優しい好人物 である，顔全体を口にして笑うような感じの体全体 からの笑顔が忘れられない.イングランド生まれで はあるが，今やスコッッマンを自認している。なお, ネイチャー・ジャパン株式会社代表の David Swinbanks 博士はエジンバラ大学で Walton 教授 の学生であった.

\section{John Harry McDonald Whitaker}

Whitaker（ウィタカー）博士（図 58）はイギリス 堆積学草創期の主要な群像の一人である.

Whitaker 博士は 1921 年 5 月 17 日イングランド の Cambridge で誕生, Cambridge大学で BA (1948), MA (1952) を, Leicester (レスタ一) 大 学で Ph. D (1966) を取得した. 職歴では, Manchester 大学講師（1948-51）を振り出しに, 新設の Leicester 大学地質学科講師 (1951-63), 同上級講師 （1963-82）を務めた. また，1960-62 年には post一 doc fellowとしてノルウェ一政府科学技術研究委 員会研究員を務めた。

博士は現在・過去の海底峡谷の形成と堆積作用に 強い関心を示し，多くの業績を挙げた（Whitaker, 1974, 1976). また, 堆積構造, 続成作用, 北海油田 の地質, ノルウェーの地質, などと幅広く研究を 行った. とくに，ガターキャスト (gutter cast) と いう小規模チャンネル状侵食構造の名前は博士の提 


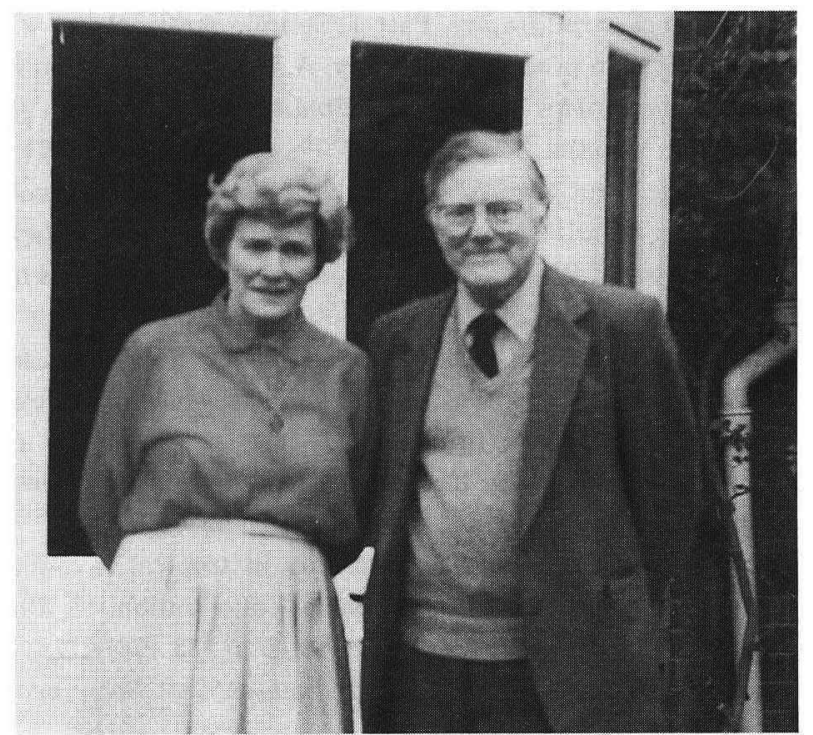

図 58 J.H. McD. Whitaker 博士と夫人（1990 年 9 月 4 日イギリス Leicester の自宅で).

唱であった（Whitaker, 1973）。

博士は王立協会派遣研究員として数回日本に滞在 して，研究を行ったことがあるので（Okada and Whitaker, 1979), 知日家である.このとき初めて四 万十帯研究の重要性を国際的に紹介するうえで中心 的役割を果たした（Taira et al., 1982）ほか，日本の 地質紹介の論文がある（Whitaker, 1982a, b).

Whitaker 博士は茶目っ気のある穏やかな好人物 で, 懐の広い人である.

\section{あとがき}

「堆積学草創期の群像」シリーズを終わるに当た り, 野外・実験・理論の三位一体の美しい学問体系 を示す現在の堆積学の成立に，このシリーズで紹介 した人たちの偉大な貢献があったことに改めて思い を致し、これらの人々と交流する機会に恵まれた幸 運に感謝している。

本シリーズの執筆の動機は, 堆積学成立の学史を まとめたおり（岡田，1998）, 堆積学の教科書に必ず 登場する研究者たちの, 手許の写真を死蔵するのは あったいないという思いからであった，写真はその 人のありようを忠実に示してくれるので，これが若 い学徒に大きい刺激になることを願っている。た だ，本シリーズでの研究者の紹介は人物写真がある 人だけに限ったため, 取り上げることができなかっ た重要な研究者がいることに悔いが残っている.し
かし，幸い，国内はむちろん，日本語で書かれては いるが国外からす，多くの人に関心を寄せられ，書 いてよかったよ思う。

シリーズを重秝るにつれて記述が充実したのは, P.F. Ballance, S. Boggs, Jr., G. Kelling, W. Nemec, H. G. Reading, F. Ricci-Lucchi, S. M. Sengupta, I. B. Singh, A. Slaczka, A.J. Smith, 孫 枢 (Sun Shu), S.K. Tandon, E.K. Walton 各氏からの個人 情報の提供之, 松本達郎, 都城秋穂, 故黒田秀隆, 大森昌衛, 高柳洋吉, 吉田 尚, 今井 功, 志岐常 正, 水谷伸治郎, 加藤 誠, 相原安津夫, 秋山雅彦, 鈴木尉元，池谷仙之，小川勇二郎，八木下晃司，矢 島道子, 武藤鉄司各氏の熱い鞭撻の賜物である.こ こに銘記してこれらの方々に深く謝意を表する．編 集幹事として本シリーズの出版に種々貴重なご配慮 をいただいた高野 修・柳本 裕両氏に感謝申上げ る.

\section{文献}

Aubouin, J., 1965 : Geosynclines. Elsevier, Amsterdam, xv + $335 \mathrm{p}$.

Ballance, P.F., 1974: An interare flysch basin in northern New Zealand : Waitemata Group (upper Oligocene-lower Miocene). Jour. Geol., 82, 439-471.

Ballance, P.F., 1976 : Evolution of the Upper Cenozoic magmatic arc and plate boundary in northern New Zealand. Earth Planet. Sci. Lett., 28, 356-370.

Ballance, P.F., 1980 : Models of sediment distibution in nonmarine and shallow marine environments in oblique-slip fault zones. Spec. Publ. Int. Ass. Sediment., 4, 229-236.

Ballance, P.F. and Reading, H.G., 1980 : Sedimentation in oblique-slip mobile zones. Spec. Publ. Int. Ass. Sediment., 4 , 265p.

Boggs, S., Jr., 1967 : A numerical method for sandstone classification. Jour. Sedim. Petrol., 37 (2), 548-555.

Boggs, S., Jr., 1984 : Quaternary sedimentation in the Japan arc-trench system. Geol. Soc. Amer. Bull., 95, 669-685.

Boggs, S., Jr., 1987 : Principles of sedimentology and stratigraphy. Merrill Publ. Co., 784p.

Boggs, S., Jr., 1992 : Petrology of sedimentary rocks. Macmillan Publ. Co., 665p.

Boggs, S., Jr., 1995 : Principles of sedimentology and stratigraphy. 2nd ed. Prentice Hall, 774p.

Boggs, S., Jr., Krinsley, D., Pye, K. and Tovey, K., 1998 : Backscattered electron microscopy and image analysis of sediments and sedimentary rocks. Cambridge Univ. Press, Cambridge, 193p.

Boggs, S., Jr. and Seyedolali, A., 1993 : Provenance of Miocene sandstones from ODP Sites in the Japan Sea. Jour. Sedi- 
ment. Soc. Japan, (38), 5-24.

Boggs, S., Jr. and Seyedolali, A., 1996 : Albitization of Miocene deep-sea sandstones from the Japan Sea backarc basin. Jour. Sediment. Soc. Japan, (43), 1-18.

Dzulynski, S. and Walton, E. K., 1965 : Sedimentary features of flysch and greywackes. Developments in sedimentology 7. Elsevier, Amsterdam, viii +274p.

Duff, P.McL.D., Hallam, A. and Walton, E.K., 1967 : Cyclic sedimentation. Developments in sedimentology 10. Elsevier, Amsterdam, 280p.

Duff, P.McL.D. and Walton, E.K., 1962 : Statistical basis for cyclothems: a quantitative study of the sedimentary succession in the east Pennine coalfield. Sedimentology, 1, 235-255.

Fritz, W.J. and Moore, J.N., 1988 : Basics of physical stratigraphy and sedimentology. Wiley \& Son, New York, ix +371p.

フリッッ，ウイリアム J・ムーア，ジョニーN [原田憲一訳], 1999 : 層序学と堆積学の基礎. 愛智出版, 東京, ix $+386 \mathrm{p}$.

Kay, M., 1951 : North American geosynclines. Geol. Soc. Amer. Mem., 48, 143p.

岡田博有, 1998 : 堆積学への道. 堆積学研究, (47), 3-15.

岡田博有, 1999 : 私が接した堆積学草創期の群像 (I ). 堆積学研 究, (49), 63-71.

岡田博有, 2000a : 私が接した堆積学草創期の群像 (II). 堆積学 研究, (50), 33-40.

岡田博有, $2000 \mathrm{~b}$ : 私が接した堆積学草創期の群像 (III). 堆積学 研究, (51), 67-77.

Okada, H. and Tandon, S. K., 1984 : Resedimented conglomerates in a Miocene collision suture, Hokkaido, Japan. In Koster, E.H. and Steel, R. J., eds., Sedimentology of gravels and conglomerates. Canad. Soc. Petroleum Geol., Mem., 10, 413-427.

Okada, H. and Whitaker, J.H.McD., 1979 : Sand volcanoes of the Palaeogene Kumage Group, Tanegashima, Southwest Japan. Jour. Geol. Soc. Japan, 85 (4), 187-196.

Taira, A., Okada, H., Whitaker, J.H.McD. and Smith, A.J., 1982: The Shimanto Belt of Japan: Cretaceous-lower Miocene active-margin sedimentation. In Leggett, J.K., ed., Trench-forearc geology. Geol. Soc. Spec. Publ., 10, 5-26.

Tandon, S.K., 1976 : Siwalik sedimentation in a part of the Kumaun Himalaya, India. Sediment. Geol., 16, 131-154.

Tandon, S. K. and Gibling, M. R., 1997 : Calcretes at sequence boundaries in Upper Carboniferous cyclothems of the Sydney Basin, Atlantic Canada. Sediment. Geol., 112, 4367.

Tandon, S. K., Sood, A., Andrews, J.E. and Dennis, P.F., 1995 : Paleoenvironments of the dinosaur-bearing Lameta Beds (Maastrichtian), Narmada valley, central India. Palaeogeogr. Palaeoclim. Palaeoecol., 117, 153-184.

Trümpy, R., 1960 : Paleotectonic evolution of the Central and Western Alps. Geol. Soc. Amer. Bull., 71, 843-907.

Vail, P.R., 1987 : Seismic stratigraphy interpretation using sequence stratigraphy. Part 1 . Seismic stratigraphy interpretation procedure. In Bally, A. W., ed. : Atlas of seismic stratigraphy. Vol. 1. AAPG Studies in Geology, 27, 1-10. Vail, P.R., Michum, R.M., Jr. and Thompson, S., III, 1977 : Seismic stratigraphy and global changes of sea level. Part 3 : Relative changes of sea level from coastal onlap. In Payton, C.E., ed. : Seismic stratigraphy-Applications to hydrocarbon exploration. AAPG Mem., 26, 63-97.

van Houten, F. B., 1961 : Climatic significance of red beds. In Nairn, A.E. M., ed., Descriptive palaeoclimatology. WileyInterscience, New York, 89-139.

van Houten, F. B., 1968 : Iron oxides in red beds. Geol. Soc. Amer. Bull., 79, 399-416.

van Houten, F. B., 1972 : Iron and clay in tropical savanna alluvium, northern Colombia: a contribution to the origin of red beds. Geol. Soc. Amer. Bull., 83, 2761-2772.

van Houten, F. B., 1973 : Meaning of molasse. Geol. Soc. Amer. Bull., 84, 1973-1976.

Walker, R. G., 1965 : The origin and significance of the internal sedimentary structures of turbidites. Proc. Yorkshire Geol. Soc., 35, 1-21.

Walker, R. G., 1975 : Generalized facies models for resedimented conglomerates of turbidite association. Geol. Soc. Amer. Bull., 86, 737-748.

Walker, R. G., 1978 : Deep water sandstone facies and ancient submarine fans : models for exploration for stratigraphic traps. AAPG Bull., 62, 932-966.

Walker, R.G., 1985 : Mudstones and thin-bedded turbidites associated with the Upper Cretaceous Wheeler Gorge conglomerates, California : a possible channel-levee complex. Jour. Sediment. Petrol., 55, 279-290.

Walker, R. G. and James, N.P., eds., 1992 : Facies models. Response to sea level change. Geol. Assoc. Canada, 409p.

Walton, E.K., 1955 : Silurian greywackes in Peeblesshire. Proc. Roy. Soc. Edinburgh, B, 65, 327-357.

Walton, E. K., 1956 : Limitations of graded bedding and alternative criteria of upward sequence in the rocks of the Southern Uplands. Trans. Edinburgh Geol. Soc., 16 (3), $262-$ 271.

Walton, E.K., 1967 : The sequence of internal structures in turbidites. Scot. Jour. Geol., 3 (2), 306-317.

Whitaker, J.H.McD., 1973 : "Gutter casts", a new name for scour-and-fill structures: with examples from the Llandoverian of Ringerike and Malmoya southern Norway. Jour. Geol. Soc. London, 129 (1), 91.

Whitaker, J.H.McD., 1974 : Ancient submarine canyons and fan valleys. In Dott, R.H., Jr. and Shaver, R.H., eds., Modern and ancient geosynclinal sedimentation. SEPM Spec. Publ., 19, 106-125.

Whitaker, J.H.McD., ed., 1976 : Submarine canyons and deepsea fans. Modern and ancient. Benchmark papers in geology 24. Dowden, Hutchinson \& Ross, Stroudsburg, xv+ 
460p.

Whitaker, J.H. McD., 1982a : The geology of Japan. Introduction. Proc. Geol. Assoc., 93 (2), 129-130.
Whitaker, J.H.McD., 1982b : Cretaceous-Paleogene geology of Southwest Japan. Proc. Geol. Assoc., 93 (2), 147-160. 